ГАЛУЗЕВИЙ АСПЕКТ РОЗВИТКУ НАЦІОНАЛЬНОГО ГОСПОДАРСТВА

УДК 338.3

DOI: $10.25140 / 2411-5215-2020-1(21)-82-90$

Ольга Тертична, Галина Рябуха, Діана Бутурлим

\title{
ЕКОЛОГО-ЕКОНОМІЧНІ ОСОБЛИВОСТІ ОРГАНІЧНОГО ЗЕМЛЕРОБСТВА УКРАЇНИ ТА ЄС
}

Ольга Тертичная, Галина Рябуха, Диана Бутурлим

ЭКОЛОГО-ЭКОНОМИЧЕСКИЕ ОСОБЕННОСТИ ОРГАНИЧЕСКОГО ЗЕМЛЕДЕЛИЯ УКРАИНЫ И ЕС

Olga Tertychna, Galyna Ryabukha, Diana Buturlym

\section{ECOLOGICAL AND ECONOMIC FEATURES OF ORGANIC AGRICULTURE OF UKRAINE AND EU}

У статті визначено важливість органічного землеробства у вирішенні питань збереження та відтворення родючості трунтів. Виокремлено ключові принципи органічного землеробства, такі як мінімізація обробітку трунту, проєктування структури посівів, використання добрив рослинного та тваринного походження, практичний досвід сільськогосподарських підприємств ЄС. Проаналізовано еколого-економічні показники ефективності виробництва органічної продукиії: екологоємність, ресурсоємність, енергомісткість врожаю, ефективність внесення органічних добрив. Виявлено пріоритетність та перспективи розвитку органічного землеробства в Украӥні.

Ключові слова: органічне землеробство; сільське господарство; мінімальний обробіток трунту; органічні добрива, ефективність виробництва.

Рис.: 1. Табл.: 1. Бібл.: 18.

В статье определены важсность органического земледелия в решении вопросов сохранения и воспроизводства плодородия почв. Выделены ключевые принципы органического земледелия, такие как минимизация обработки почвы, проектирование структуры посевов, использование удобрений растительного и животного происхождения, практический опьыт сельскохозяйственных предприятий ЕС. Проанализированы эколого-экономические показатели эффективности производства органической продукции: екологоемкость, ресурсоемкость, энергоемкость урожая, эффективность внесения органических удобрений. Выявлено приоритетность и перспективы развития органического земледелия в Украине.

Ключевые слова: органическое земледелие; сельское хозяйство; минимальная обработка почвы; органические удобрения, эффективность производства.

Рис.: 1. Табл. 1. Библ.: 18.

The article identifies the importance of organic farming in addressing the issues of preservation and reproduction of soil fertility. The key principles of organic farming, such as minimization of tillage, crop structure planning, use of fertilizers of plant and animal origin, practical experience of EU agricultural enterprises are highlighted. Ecological and economic indicators of efficiency of organic products production are analyzed: ecological intensity, resource intensity, energy intensity of harvest, efficiency of organic fertilizers application. The priority and prospects of development of organic agriculture in Ukraine are revealed.

Keywords: organic farming; agriculture; minimum tillage; organic fertilizers, production efficiency.

Fig.: 1. Table: 1. References: 18.

JEL Classification: G00

Постановка проблеми. Нині перед Україною та країнами Свропейського Союзу постає питання пріоритетності економічної ефективності вирощування сільськогосподарської продукції та збереження родючості грунтів. 3 кожним роком погіршення стану земель, їх дегуміфікація та ерозія спонукає до пошуку та запровадження методів органічного землеробства, яке базуються на грунтозахисних технологіях, відтворенні родючості, використанні органічних добрив та моделюванні структури посівів.

Аналіз останніх досліджень і публікацій. Наукова та прикладна проблема особливостей органічного землеробства висвітлені в роботах закордонних і вітчизняних учених: М. Гжибовської, М. Грунда, А. Лічмана, Ж. Родейла, Р. Штайнера та ін. Питання організаційно-технологічного впровадження органічного землеробства розглядаються в працях С. Антонця, В. Писаренка, В. Шлапака, Л. Моклячук, М. Шикули. Вагомий внесок у дослідження еколого-економічних особливостей органічного землеробства зробили О. Бородіна, О. Шкуратов, А. Вдовиченко, Н. Головченко, О. Гуторов та інші вчені.

Виділення недосліджених частин загальної проблеми. Проте, визнаючи внесок вчених у вивченні особливостей органічного землеробства, варто відзначити, що багато питань потребує подальшого дослідження. Зокрема, оцінка еколого-економічної ефективності, організаційних засад впровадження та державної підтримки виробництва органічної продукції.

(C) Тертична О. В., Рябуха Г. І., Бутурлим Д. А., 2020 
ГАЛУЗЕВИЙ АСПЕКТ РОЗВИТКУ НАЦІОНАЛЬНОГО ГОСПОДАРСТВА

Мета статті. Головною метою цієї роботи є вивчення еколого-економічних особливостей вітчизняного органічного землеробства та можливостей впровадження європейського досвіду.

Виклад основного матеріалу. 3 кожним роком питання вирощування сільськогосподарської продукції, у контексті збереження природних ресурсів, набуває дедалі більшої актуальності як для України та СС, так для і всього світу [11].

За офіційними даними загальна площа сільськогосподарських земель з органічним статусом та перехідного періоду у 2018 р. становила 309,1 тис. га, або 0,7 \% від загальної площі земель сільськогосподарського призначення України [8]. Зернові культури: кукурудза, пшениця, ячмінь, соняшник, соя - основні види органічної продукції, які експортуються з України [3]. Саме тому досягнення головних цілей органічного землеробства збереження та підвищення родючості грунтів та підвищення економічної ефективності виробництва - 3 кожним роком набувають дедалі більшої актуальності [18].

Дуальність головної мети виражається реалізацією екологічних та економічних заходів. Досвід їх успішної імплементації європейськими країнами може бути реалізований на практиці вітчизняними виробниками рослинницької продукції [12].

Основними методами біологізації рослинництва $є$ альтернативні способи обробітку грунту, разом із його мінімізацією та безплужним землеробством; відновлення біогеохімічних циклів та гумусового стану за рахунок контролю надходження органічної речовини в грунт; застосування біометодів для боротьби з бур'янами та шкідниками. Усе це $\epsilon$ базовими елементами переходу інтенсивного землеробства до вирощування органічної продукції, яка з кожним роком набуває поширення серед країн Західної Свропи [16]. Саме там перехід до екологізації рослинництва здійснюється в межах Програми розвитку сільських територій і одержує підтримку з боку Свропейського та національних урядів у вигляді дотацій та субсидій [15]. Тому європейський досвід у розвитку біологізації рослинництва мають перейняти як наші власники господарств, так і уряд України [13].

Першим і найважливішим кроком в екологізації рослинництва та покращення екологічного стану агроценозів $є$ альтернативний обробіток грунту, який найбільш сприятливо впливатиме на агрофізичні та хімічні показники грунту та збільшуватиме гумусний склад на землях, що деградують. До альтернативних способів обробітку грунту, які нині застосовують країни Свропи, належать мінімальний обробіток та система No-till.

Приблизно з кінця 1970-х до початку 1990-х pp. XX сторіччя відзначався значний приріст площ із мінімальною і нульовою технологіями, але через поширення бур'янів, хвороб та підвищення витрат, фермери масово поверталися до плужної системи. Майже схожою була ситуація як у Північних, так і в Південних країнах Свропи. 3 кінця 1990-х років прихильність фермерів знову змінилася на користь консервативного та нульового обробітку. Причина - загострення проблем із деградацією грунтів: втратою гумусу, структури, розвитком ерозії [5].

Система No-till після багатьох досліджень дедалі частіше застосовується в європейських господарствах, але також має свої обмеження через грунтові умови та поширення бур'янів. У десяти країнах Північної, Центральної і Південної Свропи під нульовим обробітком приблизно 1,1 млн га. Практично в усіх дослідженнях і у фермерській практиці доведено протиерозійну значущість нульового обробітку. Найбільш показовими $є$ приклади Норвегії, де завдяки цій технології ерозію зменшено на 90 \% порівняно 3 осіннім плужним обробітком. Для фермерів Німеччини та Франції важливо поліпшити структуру верхнього горизонту давньоорного грунту. У деяких регіонах півдня Іспанії, Італії та Греції нульовий обробіток і постійний рослинний покрив сприяють більш ефективному використанню вологи [6]. 
ГАЛУЗЕВИЙ АСПЕКТ РОЗВИТКУ НАЦІОНАЛЬНОГО ГОСПОДАРСТВА

Важливо зазначити, що при органічному землеробстві нульовий обробіток грунту $є$ недоцільним або вимагає довшого періоду переходу через збільшене використання засобів хімічного захисту рослин, яке провокується значним поширенням бур'янів, шкідників та хвороб на полях. Найголовніше завдання No-till - покращення родючості грунту, захист від ерозії та енергозаощадження.

Ірунтозахисною альтернативою глибокій оранці також є мінімальний обробіток грунту, який використовують деякі представники органічного виробництва. Так, у швейцарському господарстві Ранденгоф ще з 2006 року відмовилися від використання плуга й обробляють грунт лише поверхневим культиватором. Сівба в цьому господарстві проводиться по мульчі стрічковим способом, а на посівах штучних пасовищ застосовується комбінація лише з роторної борони та сівалки. Бур'яни на полях господарства регулюються за допомогою п'яти- та семирічних сівозмін. Завдяки мінімальному обробітку поліпшується структура грунту та збільшується кількість корисних мікроорганізмів. Через це підвищується якість продукції Ранденгофа.

Нові системи мінімального обробітку можна застосовувати в органічному землеробстві лише в тому випадку, якщо вони матимуть приблизно таку ж врожайність, як і в разі застосування плуга, і не спричиняють жодних серйозних проблем із бур'янами в довгостроковій перспективі [7].

Світовий досвід засвідчує, що в наш час технології виробництва рослинницької продукції переорієнтовуються на нові технології обробітку грунту без використання плуга. Безполицевий обробіток зменшує наслідки втручання в природне середовище грунту, збільшує вміст органічної речовини в ньому, поліпшує його структуру, регулює грунтову температуру й дає змогу грунту втримувати більше вологи.

Основний обробіток грунту без обертання скиби широко застосовують у розвинутих країнах Західної Європи. Зокрема, за інформацією фірми Fricke (Німеччина), у країнах Європейського Союзу до 50 \% площ під висів озимих та ярих зернових, а також культур суцільного висіву готують саме за енергоощадною технологією, що називається безполицева система обробітку грунту.

При ній для якісного та вчасного обробітку грунту слід застосовувати нові технології та використовувати техніку, яка легко вписується в процеси підготовки грунту з частими змінами виробничих умов. Для виконання таких робіт у господарствах використовують безплужні грунтообробні агрегати (культиватори-плоскорізи, плоскорізиглибокорозпушувачі, чизельні плуги, чизель-культиватори та інші знаряддя). Знаряддя для суцільного обробітку грунту дають можливість виконувати безполицевий основний обробіток на глибину до 20-22 см, чого цілком достатньо під час вирощування зернових і культур суцільного висіву [2].

Найбільшою проблемою, яка виникає при запровадженні альтернативних технологій обробітку грунту, є збільшення чисельності шкідників та бур'янів. Така тенденція зумовлює збільшення використання пестицидів та засобів хімічного захисту рослин, що спричиняє забруднення довкілля хімічними сполуками та знищення корисної біоти навколо угідь. Пошук біометодів для захисту рослин є одним із основних принципів при вирощуванні органічної продукції.

32007 року в країнах ЄС передбачено значне обмеження вмісту хімічних препаратів у середовищі існування людини (система REACH). Інтегрована система захисту рослин (IPM) передбачає застосування всіх засобів регулювання чисельності шкідника 3 переважаючим застосуванням природних методів контролю.

У Німеччині, Швеції, Нідерландах, Італії та Великобританії на насінні шести овочевих культурах досліджувалися засоби на основі мікроорганізмів і екстрактів рослин, а також фізичні методи - обробка гарячим вологим повітрям, гарячою водою та опромінення елек- 
тронами. Причому останні три методи виявилися найбільш успішними. Опромінення насіння електронами являє собою економічну й безпечну альтернативу протруєнню насіння та допомагає боротися зі спорами грибів і бактерій без ушкодження ендосперму.

Серед натуральних речовин для підготовки насіння найчастіше застосовують екстракти часнику, редьки та гірчиці. Наприклад, на основі порошку жовтої гірчиці в Німеччині випускається препарат Tillecur, який дозволений для застосування проти твердої сажки пшениці. Також у Німеччині на площі 14 тис. га для боротьби зі шкідниками успішно використовують трихограму. Чисельність дротяників на посівах знижують ентомофаги парковдруси, тафірініди та ін.

Згідно з рекомендаціями IFOAM (Міжнародної федерація органічного сільськогосподарського руху) в органічному землеробстві та при мінімальному обробітку грунту для зменшення забур'янення необхідне мульчування грунту, чергування колосових та листових культур, ярих та озимих культур; проведення заходів щодо контролю над бур'янами та культурами-попередниками; вибір високорослих сортів, які ефективно споживають азот, зі швидким розвитком на ранній стадії; вирощування якомога більшої кількості сидератів та проміжних культур; періодичний покіс проміжних культур; своєчасне збирання врожаю культурних рослин тощо [6].

Відновлення біогеохімічних циклів та збільшення вмісту гумусу є найголовнішим завданням грунтозберігаючої технології обробітку грунту в екологізації рослинництва. Відбувається воно через контроль за надходженням органічних речовин до грунту, яке найбільше виявляється при мінімальній та нульовій обробці, які супроводжуються використанням сидератів і великої кількості органічних решток у вигляді мульчі.

Норвезькими дослідженнями встановлено, що приорювання суміші залишків зеленого добрива конюшини й соломи ячменю весною сприяло більш ефективному використанню азоту та зменшенню його низхідної міграції.

У більшості країн Західної Свропи гичка буряків використовується не як корм, а $є$ джерелом поповнення органіки в грунті. У 100 ц гички міститься в середньому 37 кг азоту, 9 кг фосфору, 57 кг калію. У Німеччині середня врожайність гички цукрових буряків становить 450 ц/га [4].

Лізиметричні дослідження 17 ферм на південному сході Норвегії продемонстрували перевагу грунтозберігаючого обробітку грунту під рослинним покривом у зменшенні виносі нітратів. Найменшими вони були на варіантах із постійним покривом (6 кг/га), а найбільшими - на фоні оранки (35 кг/га). Приблизно такі висновки отримали при визначенні втрат фосфору [6]. Також варто зазначити, що при мінімальному обробітку грунту створюються сприятливі умови для грунтових мікроорганізмів та дощових черв'яків, які відіграють головну роль у перетворенні органічної речовини в гумус.

В Україні за різними даними від 10 до 15 млн га деградованих земель, а за 130 років склад гумусу в чорноземних грунтах зменшився на 30 \% [13]. Біодеградація гумусу орних земель пов'язана з процесами зменшення кількості рослинних решток у грунті та активністю мінералізації в ньому органічних речовин. Відновлення природної родючості передбачає пошук органічних добрив, способів їхнього внесення, розробку агротехнічних прийомів депонування і зберігання біогенних елементів гумусу, що дозволить підвищити якісні параметри грунтів. Основними причинами втрати рівня родючості $\epsilon$ дефіцит вологи. Від дефіциту вологи потерпає понад 75 \% території України [2]. Вміст вологи в українських грунтах справді набагато нижчий, ніж у Західній Європі. Протидіяти цьому можуть лише вологоощадні технології обробітку грунту, вирощування адаптованих до посушливих умов сортів і гібридів, а також відновлення зрошення. Прямий наслідок дефіциту вологи - деградація, яка призводить до зменшення врожайності, через це щороку Україна недоотримує продукції приблизно на 35 млрд грн [2]. 
ГАЛУЗЕВИЙ АСПЕКТ РОЗВИТКУ НАЦІОНАЛЬНОГО ГОСПОДАРСТВА

Перевірена багаторічним досвідом і часом європейська практика збереження грунтів та охорони їхньої родючості, яка може бути успішно імплементована й в Україні. Наприклад, австрійці підрахували, що ерозія шару грунту в 1 см (при середній щільності) призводить до незворотної втрати близько 150 тонн родючої землі з гектара. А втрати врожаю при ущільненні грунту важковаговим транспортом можуть сягати до 35 \%. Для австрійців сівозміна покликана не тільки сприяти родючості грунтів. Її супутні цілі боротьба з бур'янами, захворюваннями рослин та шкідниками. Також на меті чергування культур - ресурсозаощадження через замкнутий контур полів, оптимізація економіки праці. В Австрії культивується вирощування сумішей рослин, як проміжних культур, за що аграрії отримують субсидії від уряду: від 120 до 200 євро за гектар. Йдеться про вирощування від однієї до п'яти культур одночасно на одному полі 3 дотриманням вимог до дат посівів та обробітку землі [6].

Отже, основні заходи зі збереження родючості грунтів поєднують у собі грунто- i водозберігаючі методи, уникнення ущільнення грунту й енергетично ефективні способи його обробітку.

Іншим прикладом є органобіологічні системи обробітку грунту у Швеції та Швейцарії, для яких характерна активізація існуючої мікрофлори. Діяльність господарств грунтується на принципах наслідування природній екосистемі, в якій проєктуються сівозміни та вирощуються переважно бобово-злакові травосуміші, а залишки рослин закладаються на полях. При вирощуванні сільськогосподарських культур використовують органічні добрива (сидерати, солому, гній). Для боротьби 3 бур'янами застосовують вогневі та агротехнічні заходи. Зі шкідниками і хворобами - запобіжні заходи. Допускається застосування нетоксичних препаратів - ефірних олій рослин, порошків із водоростей і скельних порід, біодинамічних препаратів (настій із кропиви, відвар із хвоща або полину гіркого) [6].

Цінним є досвід біологічної (екологічної) системи землеробства Франції, при якій різко скорочується застосування мінеральних добрив, особливо легкорозчинних. Основне джерело живлення рослин - органічні добрива. Свіже органічне добриво за цієї технології рекомендовано не глибоко закладати в грунт, оскільки при переважанні анаеробних процесів можливе утворення токсичних для насіння і коріння продуктів. Під час компостування органічні речовини проходять фазу аеробної ферментації, тільки після цього їх можна вносити в грунт. Розмелені водорості та базальтовий пил рекомендується використовувати для зниження кислотності грунтів [7]. Велике значення має обробіток грунту, що підвищує його біологічну активність. Один з елементів біологічного землеробства - сівозміна з режимом насичення одними культурами й застосуванням сидератів. Для захисту рослин, боротьби зі шкідниками та бур'янами впроваджують такі самі заходи, як і в органобіологічній системі.

Влучним прикладом органічного землеробства в Україні $є$ підприємство ПП «Агроекологія», яке, крім досягнення екологічних цілей, демонструє зростаючі економічні показники своєї діяльності. Земельний фонд господарства становить понад 7 тис. га, на яких вирощуються зернові та кормові культури без застосування агрохімікатів. Протягом 2011-2016 pp. на більшості площ підприємство отримувало врожаї рівня інтенсивного землеробства: пшениці озимої понад 70 ц/га, кукурудзи на силос 500 ц/га, на зерно - 80 ц/га, ячменю ярого - 48 ц/га, вівса - 60 ц/га, соняшнику - 35 ц/га і більше [9]. Порівняння урожайності соняшнику, вирощеного ПП «Агроекологія», та урожайністю цієї культури по Україні за даними Державної служби статистики, ще раз доводить, що органічне землеробство не тільки безпечне, а й економічно ефективне (рис. 1). Досягнення високих показників урожайності соняшнику зумовлено раціональним проєктуванням сівозмін, систем обробітку грунту, удобрення культур, догляду за 
ГАЛУЗЕВИЙ АСПЕКТ РОЗВИТКУ НАЦІОНАЛЬНОГО ГОСПОДАРСТВА

посівами, оптимізації фітосанітарного стану посівів [9]. Конкретизуючи принципи органічного землеробства ПП «Агроекологія», можна виділити головні з них. По-перше, застосування грунозахисних технологій, при яких обробіток ведеться на глибину до 5 см. По-друге, використання гною, соломи зернових і зерновобобових, подрібнені стебла соняшнику, соняшнику сорго та ін. По-третє, контроль норм внесення органічних добрив. По-четверте, застосування біологічних методів для захисту посівів від хвороб та шкідників. По-п’яте, проєктування і корекція структури землекористування [1].

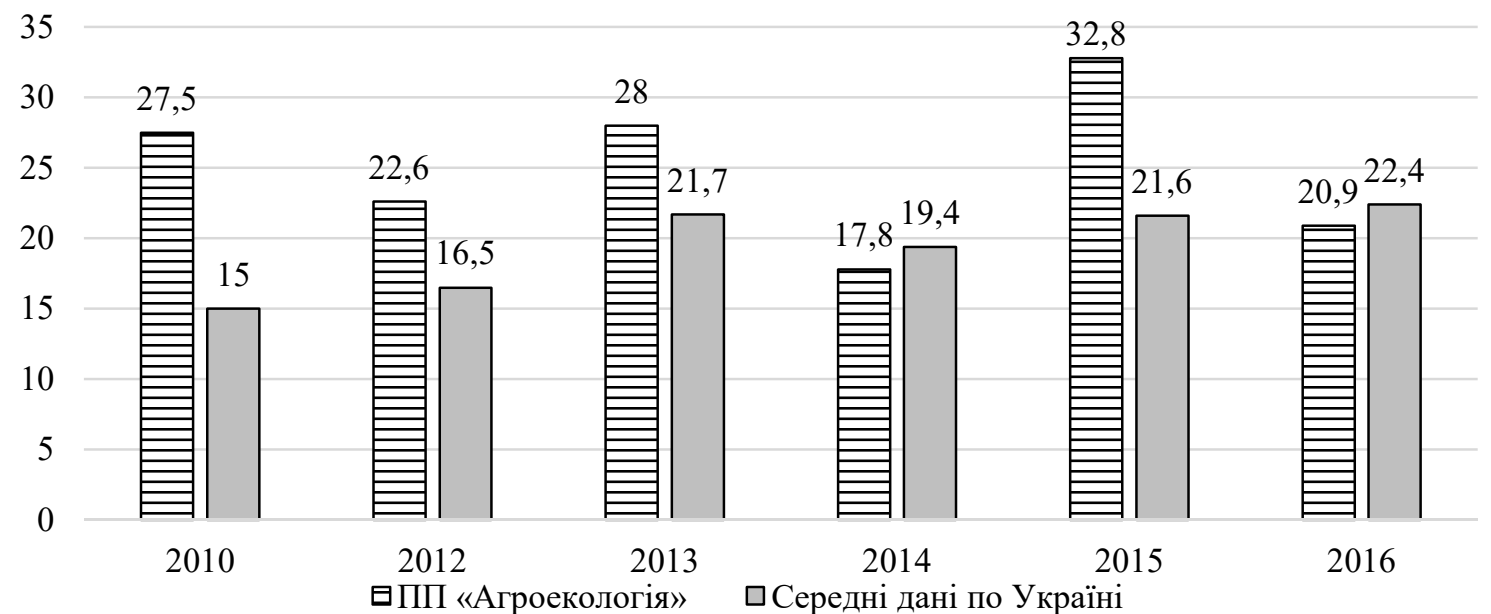

Рис. 1. Урожайність соняшнику у 2010-2016 рр., ич/га

Слід зазначити, що зменшення урожайності зернових культур стало результатом приєднанням до ПП «Агроекологія» нових господарств із низькими показниками родючості грунтів. Проте в подальшому процесі вирощування вміст гумусу, головного показника родючості грунту, на полях господарства зріс на 0,53-1,57 \%, а також достатнім вмістом основних макроелементів (азоту, фосфору, калію), причому в оптимальному співвідношенні [9].

Серед учених і практиків з органічного вирощування сільськогосподарських культур загальноприйнятою $є$ концепція, згідно з якою підвищення якості продукції неодмінно потребує збільшення витрат на ії виробництво (матеріально-технічне забезпечення, адаптація систем контролю якості, пошук нових сортів рослин тощо) [17]. Треба зазначити, що виробничі витрати в органічному виробництві вищі, і це пояснюється такими причинами: нижчий вихід продукції рослинництва на одиницю площі та більш високі трудові та технічні витрати [14]. Враховуючи вищезазначене, для визначення екологоекономічної ефективності органічного вирощування сільськогосподарської продукції, доцільним $є$ аналіз інших показників, які наведені в таблиці.

Таблиця

Еколого-економічні показники ефективності виробництва органічної сільськогосподарської продукиї

\begin{tabular}{|l|l|}
\hline \multicolumn{1}{|c|}{ Показник } & \multicolumn{1}{|c|}{ Визначення } \\
\hline Екологоємність виробництва & $\begin{array}{l}\text { Рівень допустимих шкідливих впливів на довкілля у } \\
\text { розрахунку на одиницю продукції }\end{array}$ \\
\hline Ресурсоємність виробництва & $\begin{array}{l}\text { Витрати води, повітря, земельних та інших природних } \\
\text { ресурсів у розрахунку на одиницю продукції }\end{array}$ \\
\hline Енергомісткість врожаю & $\begin{array}{l}\text { Кількість енергії, накопиченої в господарсько-цінній } \\
\text { частині врожаю }\end{array}$ \\
\hline Ефективність внесення органічних добрив & $\begin{array}{l}\text { Приріст врожаю в розрахунку на одиницю продукції після } \\
\text { внесення органічних добрив }\end{array}$ \\
\hline
\end{tabular}

Джерело: систематизовано авторами за [14]. 
ГАЛУЗЕВИЙ АСПЕКТ РОЗВИТКУ НАЦІОНАЛЬНОГО ГОСПОДАРСТВА

Отже, нами запропоновані основні показники для визначення ефективності виробництва органічної сільськогосподарської продукції, які можуть бути доповненні залежно від спеціалізації суб'єкта господарської діяльності.

Висновки і пропозиції. Перед сільським господарством України на сучасному етапі стоять складні завдання щодо визначення шляхів подальшого розвитку. Погіршення стану земель, їх дегуміфікація та ерозія, забруднення грунтів та вирощеної продукції пестицидами, радіонуклідами, важкими металами, нітратами й нітритами спонукало до пошуку та запровадження методів екологізації сільського господарства. Враховуючи сучасний стан та деградаційні процеси українських грунтів, потрібно розробити й реалізувати цілу низку заходів. Найважливішими з них, на нашу думку, є: мінімізація обробітку грунтів, впровадження науково обгрунтованих сівозмін; підвищення обсягів внесення органічних добрив, зокрема шляхом використання залишків врожаю (солома, стерня, подрібнені стебла соняшнику, кукурудзи, сорго, гичка), посівів бобових культур, багаторічних трав та сидератів.

Отже, органічне виробництво продукції рослинництва, як і всього сільського господарства, $\epsilon$ найважливішим фактором його успішного та сталого розвитку. Збереження грунтів, довкілля та виробництво екологічно безпечної продукції $\epsilon$ головним обов'язком як і українських, європейських, так і світових виробників.

\section{Список використаних джерел}

1. Антонець С. С., Антонець А. С., Писаренко В. М. Органічне землеробство: 3 досвіду ПП «Агроекологія» Шишацького району Полтавської області : практ. рек. / за ред. В. М. Писаренка. Полтава : РВВ ПДАА, 2010. 198 с.

2. Безполицевий обробіток грунту в Україні. Пропозиція: вебсайт. URL: https://propozitsiya.com/bezpoliceviy-obrobitok-gruntu-v-ukrayini.

3. Вдовенко Н. М., Паламар I. О. Формування вітчизняного ринку комбікормів в умовах глобалізації та євроінтеграції. Глобальне управління та економіка. 2015. № 1 (1). С. 162-168.

4. Веремеєнно С. І., Трушева С. С. Біологічні системи землеробства : навчальний посібник. Рівне : НУВГП, 2011. 196 с.

5. Контури розумного землеробства. Агроеліта: вебсайт. URL: https://agrotimes.ua/article/ konturi-rozumnogo-zemlerobstva.

6. Медведев В. В. Нульовий обробіток грунту в європейських країнах. Харків : ТОВ «ЕДЕНА», 2010. 202 c.

7. Мінімальний обробіток грунту Застосування в органічному землеробстві. Швейцарськоукраїнський проєкт «Розвиток органічного ринку в Україні». URL: https://ukraine.fibl.org/ fileadmin/documents-ukraine/Booklets/Zemlja_A4.pdf.

8. Міністерство аграрної політики та продовольства України. URL: https://agro.me.gov.ua/ ua/napryamki/organichne-virobnictvo/organichne-virobnictvo-v-ukrayini.

9. Писаренко В. М., Антонець А. С., Лукьяненко Г. В., Писаренко П. В. Система органічного землеробства агроеколога С. С. Антонця / за ред. В. М. Писаренка. Полтава, 2016. 131 с.

10. Пінчук О. В., Тертична О. В., Бородай В. П. Перспективні напрями екологічних досліджень у галузі тваринництва. Агроекологічний журнал. 2017. № 2. С. 44-48.

11. Рябуха Г. І., Кульпінський С. В. Експортний потенціал галузі тваринництва. Чернігівський науковий часопис. 2016. № 1 (7). С. 19-25.

12. Селінний М. М. Напрями розвитку біоекономіки України. Науковий вісник ЧДІЕУ. 2014. № 1 (21). С. 14-19.

13. Сус Т. Й. Фінансування розвитку екологічного сільгоспвиробництва в країнах Європейського Союзу. Органічне виробництво і продовольча безпека. Житомир : Полісся, 2013. 492 с.

14. Шкуратов О. І., Чудовська В А., Вдовиченко А. В. Органічне сільське господарство: еколого-економічні імперативи розвитку : монографія. Київ : ТОВ «ДІА», 2015. 248 с. 
ГАЛУЗЕВИЙ АСПЕКТ РОЗВИТКУ НАЦІОНАЛЬНОГО ГОСПОДАРСТВА

15. Burlutskiy S. V., Burlutska S. V., Marhasova V. G., Sakun O. S. (2019). The relationship between short-term fluctuations and stages of economic cycle: The case of Ukraine. Espacios. 2019. Vol. 40, No. 10. URL: http://www.revistaespacios.com/a19v40n10/a19v40n10p10.pdf.

16. Koval V. V., Derii Z. V., Sedikova I. O. The role of the agricultural sphere in the context of food security. Scientific bulletin of Polissia. 2018. № 4 (16). P. 21-27.

17. Shkarlet S., Dubyna M. Features of the cognitive approach application to the essence of the financial services market identification. Economic Annals-XXI. 2016. Vol. 158, Issue 3-4(2). P. 70-74.

18. Vdovenko N., Deriy J., Seliverstova L., Kurmaiev P. Formation of the information economy: Organizational and financial aspects. International Journal of Supply Chain Management. 2019. Vol. 8(4). P. 956-961.

\section{References}

1. Antonets, S. S., Antonets, A. S., \& Pysarenko, V. M. (Ed.) (2010). Orhanichne zemlerobstvo: z dosvidu PP «Ahroekolohiia» Shyshatskoho raionu Poltavskoi oblasti [Organic farming: from the experience of PE "Agroecology" Shishatsky district of Poltava region]. Poltava: RVV PDAA.

2. Bezpolytsevyi obrobitok gruntu $\mathrm{V}$ Ukraini [No-till in Ukraine]. https://propozitsiya.com. Retrieved from https://propozitsiya.com/bezpoliceviy-obrobitok-gruntu-v-ukrayini.

3. Vdovenko, N. M., \& Palamar, I. O. (2015). Formuvannia vitchyznianoho rynku kombikormiv v umovakh hlobalizatsii ta yevrointehratsii [Formation of the domestic feed market in the context of globalization and European integration]. Hlobalne upravlinnia ta ekonomika - Global governance and economics, 1 (1), 162-168.

4. Veremeienno, S. I., \& Trusheva, S. S. (2011). Biolohichni systemy zemlerobstva [Biological systems of agriculture]. Rivne: NUVHP.

5. Kontury rozumnoho zemlerobstva [The contours of smart farming]. https://agrotimes.ua. Retrieved from https://agrotimes.ua/article/konturi-rozumnogo-zemlerobstva.

6. Medvedev, V. V. (2010). Nulovyi obrobitok gruntu v yevropeiskykh krainakh [No-till in European countries]. Kharkiv: TOV «EDENA».

7. Minimalnyi obrobitok gruntu Zastosuvannia v orhanichnomu zemlerobstvi. Shveitsarskoukrainskyi proiekt «Rozvytok orhanichnoho rynku v Ukraini» [Minimum tillage Application in organic farming. Swiss-Ukrainian project "Development of the organic market in Ukraine"]. Retrieved from https://ukraine.fibl.org/fileadmin/documents-ukraine/Booklets/Zemlja_A4.pdf.

8. Ministerstvo ahrarnoi polityky ta prodovolstva Ukrainy [Ministry of Agrarian Policy and Food of Ukraine]. agro.me.gov.ua. Retrieved from https://agro.me.gov.ua/ua/napryamki/organichnevirobnictvo/organichne-virobnictvo-v-ukrayini.

9. Pysarenko, V. M. (Ed.), Antonets, A. S., Lukianenko, H. V., \& Pysarenko, P. V. (2016). Systema orhanichnoho zemlerobstva ahroekoloha S. S. Antontsia [System of organic farming of the agroecologist S. S. Antonets]. Poltava.

10. Pinchuk, O. V., Tertychna, O. V., \& Borodai, V. P. (2017). Perspektyvni napriamy ekolohichnykh doslidzhen u haluzi tvarynnytstva [Perspective directions of ecological researches in the animal husbandry]. Ahroekolohichnyi zhurnal-Agroecological journal, 2, 44-48.

11. Ryabukha, H. I., \& Kulpinskyy, S. V. (2016). Eksportnyi potentsial haluzi tvarynnytstva [Export potential of the livestock industry]. Chernihivskyi naukovyi chasopys - Chernihiv scientific journal, 1 (7), 19-25.

12. Selinnyi, M. M. (2014). Napriamy rozvytku bioekonomiky Ukrainy [Directions of development of bioeconomy of Ukraine]. Naukovyi visnyk ChDIEU - Scientific Bulletin of ChDIEU, 1 (21), 14-19.

13. Sus, T. Y. (2013). Finansuvannia rozvytku ekolohichnoho silhospvyrobnytstva $v$ krainakh Yevropeiskoho Soiuzu. Orhanichne vyrobnytstvo i prodovolcha bezpeka [Financing of the development of organic farming in the European Union. Organic production and food security]. Zhytomyr: Polissia.

14. Shkuratov, O. I., Chudovska, V A., \& Vdovychenko, A. V. (2015). Orhanichne silske hospodarstvo: ekoloho-ekonomichni imperatyvy rozvytku [Organic agriculture: ecological and economic imperatives of development]. Kyiv: TOV «DIA». 
ГАЛУЗЕВИЙ АСПЕКТ РОЗВИТКУ НАЦІОНАЛЬНОГО ГОСПОДАРСТВА

15. Burlutskiy, S. V., Burlutska, S. V., Marhasova, V. G., Sakun, O. S. (2019). The relationship between short-term fluctuations and stages of economic cycle: The case of Ukraine. Espacios, 40 (10). Retrieved from http:/www.revistaespacios.com/a19v40n10/a19v40n10p10.pdf.

16. Koval, V. V., Derii, Z. V., Sedikova, I. O. (2018). The role of the agricultural sphere in the context of food security. Scientific bulletin of Polissia, 4 (16), 21-27.

17. Shkarlet, S., Dubyna, M. (2016). Features of the cognitive approach application to the essence of the financial services market identification. Economic Annals-XXI, 158 (3-4(2)), 70-74.

18. Vdovenko, N., Deriy, J., Seliverstova, L., Kurmaiev, P. (2019). Formation of the information economy: Organizational and financial aspects. International Journal of Supply Chain Management, 8(4), 956-961.

Тертична Ольга Василівна - доктор біологічних наук, старший науковий співробітник, Інститут агроекології і природокористування, Національна академія аграрних наук України (вул. Метрологічна, 12, м. Київ, 03143, Україна).

Тертичная Ольга Васильевна - доктор биологических наук, старший научный сотрудник, Институт агроэкологии и природопользования, Национальная академия аграрных наук Украины (ул. Метрологическая, 12, г. Киев, 03143, Украина).

Tertychna Olga - Doctor of Biological Sciences, senior research fellow, Institute of Agroecology and Environmental Management, National Academy of Agrarian Sciences of Ukraine (12 Metrolohichna Str., 03143 Kyiv, Ukraine).

E-mail: olyater@ukr.net

ORCID: https://orcid.org/0000-0002-9514-2858

Рябуха Галина Ігорівна - кандидат економічних наук, старший викладач кафедри аграрних технологій та лісового господарства, Чернігівський національний технологічний університет (вул. Шевченка, 95, м. Чернігів, 14035, Україна).

Рябуха Галина Игоревна - кандидат экономических наук, старший преподаватель кафедры аграрных технологий и лесного хозяйства, Черниговский национальный технологический университет (ул. Шевченко, 95, г. Чернигов, 14035, Украина).

Ryabukha Galyna - PhD in Economics, senior lecturer of Department of Agricultural Technologies and Forestry, Chernihiv National University of Technology (95 Shevchenka Str., 14035 Chernihiv, Ukraine).

E-mail: g.ryabukha@gmail.com

ORCID: https://orcid.org/0000-0003-2146-7489

Бутурлим Діана Анатоліївна - здобувачка вищої освіти, Чернігівський національний технологічний університет (вул. Шевченка, 95, м. Чернігів, 14035, Україна).

Бутурлим Диана Анатолиевна - соискательница высшего образования, Черниговский национальный технологический университет (ул. Шевченко, 95, г. Чернигов, 14035, Украина).

Buturlym Diana - Applicant for higher education, Chernihiv National University of Technology (95 Shevchenka Str., 14035 Chernihiv, Ukraine).

E-mail: dianabuturlym@ukr.net

Тертична О., Рябуха Г., Бутурлим Д. Еколого-економічні особливості органічного землеробства України та ЄС. Проблеми $i$ перспективи економіки та управління. 2020. № 1 (21). С. 82-90. 